\title{
The Socialization Process as Bane of Gender Inequalities in Nigeria
}

\author{
Eteng Ikpi Etobe (PhD) ${ }^{1}$, Ntongha Eni Ikpi ${ }^{2}$, Chukwudi Charles Ezikeudu ${ }^{3}$, Utibe E. I. Etobe ${ }^{4}$ \\ ${ }^{1}$ Department of Sociology, University of Calabar, Calabar, \\ ${ }^{2,3}$ Department of Sociology, University of Calabar, Calabar
}

${ }^{4}$ Department of Nursing Services, University of Calabar Teaching Hospital, Calabar

\begin{abstract}
Gender inequalities traverse the nooks and crannies of every society. From the minutest unit of the family to the mega social organizations, inequality darts the lanes and planes of human existence. Various paradigmatic themes and perspectives have been adduced by scholars to explain this social phenomenon truncating the equi-balance of social interactions. The structural functionalists for instance, see gender inequalities as necessary and functional to social existence and advocate for its continuity and perpetuation in society. Egalitarianism protagonists have seen patriarchy, its ideology and structure as the bedrock on which gender inequalities thrive. While this paper is not a critique of this stance, the authorial position of this paper is an examination of the socialization process as the primal obstacle to the dismantling and total collapse of gender inequalities in society. Synoptic prescriptions from this paper would contribute significantly to the global search for ways of eradicating gender inequalities especially in patriarchal societies of the world.
\end{abstract}

Keywords: gender, inequalities, socialization.

\section{Introduction}

George Orwell (1945:52) once noted that "all animals are equal but some animals are more equal than others". This assertion goes a long way in supporting the issue of social inequality which some people say is embedded in nature, while others say that it is a social creation. Etobe (2003:1) observes that issues that seem to strengthen and perpetuate inequality in society range from sex, race, colour, religion, wealth, cultural practices, etc. Social inequality is ubiquitous, inevitable, ancient in origin, diverse in both form and degree as well as consequential in all societies of existence. How social inequality is structured and maintained in all societies and intergenerationally has been of great social concern to Social scientists and other disciplines involved in the study of humanity over time. They have sort realizable and pragmatic solutions to end this social cankerworm without success and this has ignited further search to know the causes, course and consequences of this problem.

\section{Gender Inequalities in Nigeria: The 3 C's Analysis}

An examination of the three C's of gender inequalities involves an estimation of its causes, course and consequences. According to the biblical account, Adam and Eve (man and woman) were created in the image and likeness of God. Both male and female were created equal and lived as equals in the Garden of Eden without any problem. Society was at that time egalitarian. Both of them were charged to eat of everything that was in this Garden except eating the fruit of knowledge of good and evil which was in the midst of the Garden. The "serpent beguiled the woman and she ate of it and gave to the man and he did eat" (Gen. 2:15-17). This brought about the fall of man and woman. From this account, the pathway to inequality was created after the pronouncement of the "trial judge" who said to the woman "...and your desires shall be to thy husband and he shall rule over you" (Gen. 3:1-18). This "judgment" lends credence and support to why women are relegated to the subservient position in society. Women are not given their rightful place in the scheme of things because of their assumed role in the fall of man. Another causal factor of gender inequalities is patriarchy which according to Thesaurus is a form of social organization in which the father is the supreme authority in the family, clan or tribe and descent is reckoned through the male line with the children belonging to the father's clan or tribe. Historically, patriarchy operates through the disproportionate conferment of leadership status or formal titles to men, a tradition characterized by casting all women as naturally unsuited or unfit to lead the men, no matter what talents and expertise they might possess. Patriarchal social traditions are universal in all human societies although some societies are more patriarchal than others. These traditions take the physical strength disparity between the sexes as sign of a general female inferiority, a "natural order" that indicates women are meant to be subordinate. Patriarchy is seen by radical scholars as just some conspiracy theory that blames all men, even decent men for the woes of women.

Examining the course of gender inequality simply involves an understanding of its existence and continuity intergenerationally. Gender inequality has been perpetuated in all societies because of socio-cultural values and norms handed down from father to son and mother to daughter. It tends to be reproduced from one generation to another and because it is embedded in cultural artifacts, it has been internalized in all fabrics of society. The fact that religion seems to support some forms of it, makes it thrive better in most societies especially where certain religions are regarded as State apparatus of social cohesion and solidarity. Inequality is being reproduced in such a vicious cycle that mothers indoctrinated their children to maintain the gender roles assigned to them by their culture. Mothers and fathers rehearse these differential roles to their children so that they

\section{Volume 4 Issue 11, November 2015}




\section{International Journal of Science and Research (IJSR) \\ ISSN (Online): 2319-7064 \\ Index Copernicus Value (2013): 6.14 | Impact Factor (2014): 5.611}

see these roles as normal and dare not to challenge them even if they are not in consonance with socio-cultural reality. This is seen across all shades of human interactions from the family, school, church, clubs and/or other social organizations. Jenkins (1996) notes that individuals must recognize the role that adherence to traditional gender roles play in maintaining gender inequality.

The consequence of gender inequality is primarily evident in gender discrimination, gender bias and gender-based violence. This has resulted in various shades of gender aggressiveness in the family, workplace and other areas of social interactions. As a result of this consequence, socioeconomic development of society is slowed down or ineffective because of the absence of an important part (women) in the development process. The finesse component of development which the women represent is eliminated in the developmental aspiration of any society that does not include women in the mainstreaming of policy and programmes especially those affecting women and children. The holistic development of society is not possible if women are extracted from the process of that development because this form of development would be lopsided.

\section{Socialization Process As Explanation For Gender Inequalities in Nigeria}

Socialization is defined simply as the process by which children and adults learn from others. Human infants are born without any culture. They must be transformed by their parents, teachers and others into cultural and socially adept animals. During socialization, we learn the language of the culture we are born into, as well as the roles we are to play in life. For example, girls learn how to be mothers, sisters, wives, and friends. In addition, they learn about the occupational roles that their society has in store for them. In the same vein, the boys learn how to be fathers, brothers, husbands and friends as well as occupational roles assigned them by society (Fulcher \& Scott, 2007; Haralambos, 2008 ). O'Neils (2011) observes that, socialization is very important in the process of personality formation. According to him, personality refers to all of an individual's complex mental characteristics that make him/her unique from other people. It includes all of the patterns of thought, emotions and other mental traits that cause us to do and say things in particular ways. While much of human personality is the result of our genes, by encouraging specific beliefs and attitudes as well as selectively providing experiences, some other aspects of our personality are learned from the environment. Like the Social Learning theorists would want us to believe that, all infants are born "tabula rasa", meaning an "empty slate or blackboard" and that, whatever an individual becomes, is written in him/her by the society of his/her primary socialization. Successful socialization can result in uniformity within a society. If all children receive the same socialization, it is likely that they will share the same beliefs and expectations. This fact has been a strong motivation for national governments around the world to standardize education and make it compulsory for all children. Deciding what things are taught and how they are taught is a powerful political tool for controlling people (O'Neils, 2011). Although socialization begins shortly after birth, early childhood is the most intense and most crucial period of socialization. It is then that we acquire language and learn the fundamentals of our culture. It is also when much of our personality takes shape. Most of the crucial early socialization is done informally "under the supervision of women and girls" (O’Neils, 2011).

Initially mothers and their female relatives are primarily responsible for socialization. Later, when children enter the lower school grades, they are usually under the control of women teachers. Almost in every society, baby-sitters are most often teenage girls or nannies; older sisters or even grandmothers. It is important to note that, "we generally socialize our children in much the same way that our parents socialized us". Parsons (1970) notes that socialization involves learning different gender roles in which women are more expressive or emotional and men more instrumental. Ann Oakley believes that gender roles are culturally rather than biologically produced. That, whatever the biological differences between males and females, it is the culture of a society that exerts most influence in the creation of masculine and feminine behavior. Socialization notes Oakley (1972), shapes the behavior of girls and boys from an early age from these four main dimensions:

1) That, the child's self-concept is affected by manipulation by mothers who tend to pay more attention to girls' hair and to dress girls in "feminine clothes".

2) That, differences in gender behavior are achieved through what she called "canalization" which involves the direction of boys and girls towards different objects. This is more obvious and evident in the provision of toys which encourage the girl-child to rehearse her expected adult roles as mother and housewife. For example, the girl-child is given a doll, soft toys and miniature domestic objects and appliances to play with, which are expressive of who she is manipulated to be and the path to follow in the course of her socialization. Conversely, the boy-child is given toys which encourage more practical, logical and aggressive behavior. For example, toy-guns, aeroplane, caterpillar, truck, train, horse, etc. It is significant to note that, mothers play the most crucial role in the manipulation and canalization of children in the process of socialization since they are the primary change-agent at this stage of their development.

3) That, the use of verbal appellations by the mothers lead children to identify with their gender and imitate adults of the same gender. For example, "you are a naughty boy", "you are an aggressive boy", "you like fighting like your father", "boys love playing football", etc; and "that's my good girl", "girls are not naughty", "dress nicely like a girl", etc.

4) That, males and females are exposed and indoctrinated to perform different activities. For example, girls are particularly encouraged to become involved in domestic or household chores like sweeping the floor, dishwashing, washing of clothes, cooking, etc, while the boys are encouraged to be involved in outdoor and strenuous activities like hunting, lumbering, climbing, etc.

In line with Oakley's argument, it can be deduced that women who are the primary agent of socialization could be seen as instrumental to the creation of gender inequality in society. This is achieved through manipulating the children of different sexes to behave in particular ways and to follow

\section{Volume 4 Issue 11, November 2015}




\section{International Journal of Science and Research (IJSR) \\ ISSN (Online): 2319-7064 \\ Index Copernicus Value (2013): 6.14 | Impact Factor (2014): 5.611}

different "canals of lifestyle" as are defined by the mother during the course of socializing the children. Again, the use of verbal appellations by using crude, aggressive and queer concepts to describe the male infant makes him associate himself with these vulgar and animalistic attitudes and behaviour as he grows. Conversely, the girl is described with sweet, sexy, adoring, desirous and pretty concepts which makes her see herself as different and even more important than her male counterpart. This is one of the reasons of sibling rivalry in the family with its attendance consequences.

Talcotts Parsons $(1937,1951,1955,1959,1970)$ argues that, the family is the most important agency of primary socialization and women take primary responsibility for childcare. Cooper (1972) on his part argues that, the family specializes in the formation of roles for its members rather than laying down conditions for free assumption of identity. Thus children are taught to play the roles of son and daughter, male and female although such roles are now constricting. They confine behavior within narrow limits and restrict the development of self. They lay the groundwork for indoctrination at school and society in general. Again, Cooper (1972) sees the family as an ideological conditioning device which conditions children to accept their exploitation and submit to those in authority without question. Handel (2006) on his part observes that at birth the newborn is not able to take part in society by cooperating with others for two reasons. First, the newborn is physically and mentally immature and second, the infant is unsocialized. As the child grows he/she goes through the biological maturation and at the same time undergoes a process of socialization which enables him/her to function as a member of the society. In order to survive, this baby must receive care from one or more caregivers. It is worthy of note that, the primary caregiver, primary agent of socialization, and primary teacher and role-model to the baby is the mother. She teaches him/her the theory and practice of love, hate, smile, frown, laughter, anger, agitation, cooperation, greetings, giving or refusal to give, and identification of objects in society. These teachings are reinforced as the child learns to interact with peers at school or Sunday-school in church. Also, Parsons sees school as an important agency of secondary socialization. That is, it is a focal socializing agency because it acts as a bridge between the home and society at large. It is important to note that, in most societies, females serve as teachers in both primary and secondary schools, where they continue in the indoctrination of children of different sexes into differential roles based on biological features (sex).

Jenkins (1996) in her work "Mothers, Daughters and Political Socialization" observes that supportive attitudes towards equal rights are insufficient for remedying the baneful effects of gender discrimination and that individuals must recognize the role that adherence to traditional gender roles play in maintaining gender inequality. She emphasized that women should resist the pull of traditional gender roles that often limit their choices outside the home. The extent to which women today adhere to norms that ultimately serve to keep them in their place is critical for understanding what it means to say that one is supportive of equal rights for women. However, it should be emphasized that, political socialization of women to maintain a commitment to ending gender discrimination and challenge the constraints imposed by traditional gender roles which limit women's participation in public life should be intensified, so that political outcomes are reflective of women's interests (O’Neils, 2011; Jenkins, 1996; Rommel \& LaRossa 1997). Jenkins (1996) also observes that two forces are influential in shaping women's understanding of gender roles and behaviors. First, is the role of intergenerational transmission which is reflective of maternal influence; and second, the importance of generational effects and differences among women in their attitudes and behavior relative to gender roles that might be attributed to the nature of the times during their formative years.

\section{Dismantling the Strongholds of Gender Inequalities in Nigeria}

In spite of the perpetuation of gender inequalities in Nigeria as a result of the role socialization has played intergenerationally, and its adverse consequences which has affected the socio-political and economic development of society, something has to be done toward dismantling the promoters (predisposing and precipitating variables) of gender inequalities. The core perpetuator or promoter is the nature and structure of patriarchy and its modus operandi. The Nigerian society with its plural structure of over 350 linguistic nationalities is strongly entrenched in patriarchal traditions supported by religious tenets. Akin to this core promoter is the peripheral promoters such as male-child preference, poverty, illiteracy and ignorance, superstitious beliefs, and narrow worldview of most people in Nigeria.

To successfully dismantle these strongholds would entail a purposive and deliberate action by all well-meaning citizens of the Nigerian society. Insofar as gender inequality has been identified as a social problem and a cog in the wheel of progress of development, a collective concerted effort would bring positive change and desired results. Some of the ways these promoters of gender inequalities could be removed are through resocialization and cultural reconscientization of the society, social redefinition of patriarchy to incorporate integration of the females in the administrative machinery of the family, community and entire society. This seems to be effectively implemented by all members of the comity of nations through the ratification of the $35 \%$ affirmative action on women. Again, efforts should be geared towards a political and economic empowerment of women which will give them equal and ample opportunity to make choices and decisions favorable to them. In the same vein, what constitutes morality in society should be redefined to reflect the females' conception and perception of morality and not just the male elitists' perception as is the case presently. The issue of heirship and progenitor should as well be redefined in our society so that both males and females are given equal chances and rights to ascend the throne of their fathers and inherit wealth and income from their fathers.

If the walls of inequality are dismantled and a holistic reconstruction of society is carried out, an integrative and egalitarian society would emerge. A society where everybody is seen and treated as equals, not because of sexual endowment but on the principle of humanness.

\section{Volume 4 Issue 11, November 2015}


Although Jenkins (1996) strongly believes that, women are to be blamed for the problems associated with not living up to gendered expectation since they institute, promote and encourage differential gender socialization, one could strongly argue that, these cultural socialization are prescribed as norm and values especially in patriarchal societies.

\section{Conclusion}

This discourse has taken a critical analysis of gender inequalities in Nigeria, examining its causes, course and consequences. It has as well anchored its argument on the fact that, "faulty" socialization is the bane or primal promoter of gender inequalities in society. The fact that patriarchal traditions re-enforces the functionality of most societies lends credence to the perpetuity of gender inequality. Some of the recommendations of this paper to ending gender inequalities include amongst other, a redefinition of the concept of patriarchy, the abolition of male-child preference and heirship in society, the principle of resocialization and cultural reconscientization of the male population as well as political and economic empowerment of the women population. In addition, the $35 \%$ United Nations affirmative policy on women should be practically enforced in all countries. Appropriate legislations for the protection of women against violence and discrimination on grounds of sex should be enacted and pragmatically enforced. More proactive collaborative actions e.g. lobbying, dialogue, etc, by women should be vigorously pursued at all levels of administration and governance in order to integrate the women in policy decision in the country.

\section{References}

[1] Cooper, D. (1972). The Death of the Family. Harmondsworth. Penguin.

[2] Etobe, E. I. (2003). The Nature and Structure of Social Inequality. Calabar. Baye Communications Ltd.

[3] Fulcher, J. \& Scott, J. (2007). Sociology. $3^{\text {rd }}$ Ed. New York. Oxford Univ. Press

[4] Handel, G. (eds) (2006). Childhood Socialization. $2^{\text {nd }}$ Ed. New Brunswick. Aldine Transaction.

[5] Haralambos, M. \& Holborn (2008). Sociology: Themes $\&$ Perspectives. $7^{\text {th }}$ Ed. London. HarperCollins Publishers Ltd.

[6] Jenkins, K. (1996). Mothers, Daughters and Political Socialization. www.temple.edu/tempress/title/2236_reg.htm/ accessed on Friday, $6^{\text {th }}$ February, 2015.

[7] Oakley, A. (1972). Sex, Gender and Society. London. Temple Smith.

[8] O'Neil, D. (2011). Socialization. www.anthro.palomar.edu/social/default.htm accessed on Friday, 6th February, 2015.

[9] Parsons, T. (1970). Equality and Inequality in Modern Society. New Jersey. Printice-Hall.

[10]Rommel, D. \& LaRossa, R. (1997). Fatherhood and Motherhood in a Diverse and Changing World. Michigan Family Review Vol. 3:1 